NBER WORKING PAPER SERIES

\title{
WHY DO AMERICANS WORK SO MUCH MORE THAN EUROPEANS?
}

\author{
Edward C. Prescott \\ Working Paper 10316 \\ http://www.nber.org/papers/w10316 \\ NATIONAL BUREAU OF ECONOMIC RESEARCH \\ 1050 Massachusetts Avenue \\ Cambridge, MA 02138 \\ February 2004
}

This is the 2002 Erwin Plein Nemmers Prize in Economics lecture, presented April 21, 2003, at Northwestern University. I would like to thank Simona Cociuba, T. C. Tong, Alexander Ueberfeldt, and Sami Alpanda for excellent research assistantship, as well as the participants of my lectures at Berlin, the Bank of England, Industry Canada, Tokyo University, the University of Toulouse, and the University of Illinois. I also acknowledge the financial support of the National Science Foundation under SES 9986667. The views expressed herein are those of the authors and not necessarily those of the National Bureau of Economic Research.

(C)2004 by Edward C. Prescott. All rights reserved. Short sections of text, not to exceed two paragraphs, may be quoted without explicit permission provided that full credit, including $(\subset$ notice, is given to the source. 
Why Do Americans Work so Much More than Europeans?

Edward C. Precott

NBER Working Paper No. 10316

February 2004

JEL No. E6, H3

\begin{abstract}
Americans now work 50 percent more than do the Germans, French, and Italians. This was not the case in the early 1970s when the Western Europeans worked more than Americans. In this paper, I examine the role of taxes in accounting for the differences in labor supply across time and across countries, in particular, the effect of the marginal tax rate on labor income. The population of countries considered is that of the G-7 countries, which are the major advanced industrial countries. The surprising finding is that this marginal tax rate accounts for the predominance of the differences at points in time and the large change in relative labor supply over time with the exception of the Italian labor supply in the early 1970s. This finding has important implications for policy, in particular for making social security programs solvent.
\end{abstract}

\author{
Edward C. Prescott \\ Research Department \\ Federal Reserve Bank of Minneapolis \\ 90 Hennepin Ave. \\ Minneapolis, MN 55480-0291 \\ and NBER \\ edward.prescott@asu.edu
}




\section{Introduction}

Americans, that is, residents of the United States, now work much more than do Europeans. Using labor market statistics from the Organisation for Economic Co-operation and Development (OECD), I find that Americans on a per person aged 15-64 basis work in the market sector 50 percent more than do the French. This was not always the case. In the early 1970s, Americans allocated less time to the market than did the French. The comparisons between Americans and Germans or Italians are the same. Why are there such large differences in labor supply across these countries? Why did the relative labor supplies change so much over time? In this lecture, I determine the importance of tax rates in accounting for these differences in labor supply for the major advanced industrial countries and find that tax rates alone account for most of these differences in labor supply.

This finding has important implications for policy in particular for financing social security retirement programs in Europe. On the pessimistic side, one implication is that increasing tax rates will not solve the problem of these under funded plans, because increasing tax rates will not increase revenue. On the positive side, the system can be reformed in a way that makes the young better off while honoring promises to the old. This can be accomplished by modifying the tax system so that when an individual works more and produces more output, the individual gets to consume a larger fraction of this increase output.

The major advanced industrial countries, which used to be called the G-7 countries, are the European countries France, Germany, Italy, and the United Kingdom, plus Canada, Japan, and the United States. For these countries comparable and sufficiently good statistics are available to carry out this investigation. The data sources are the United Nations system of national accounts (SNA) statistics and the OECD labor market statistics and purchasing 
power GDP numbers. ${ }^{1}$ The periods considered are 1970-74 and 1993-96. The later period was chosen because it is the most recent period prior to the U.S. telecommunications/dotcom boom of the late 1990s, a period when the relative size of unmeasured output was probably significantly larger than normal and there may have been associated problems with the market hours statistics. The early period was selected because it is the earliest one for which sufficiently good data are available to carry out the analysis. The relative numbers subsequent to 2000 are pretty much the same as they were in the pre technology boom period 1993-96.

I emphasize that my labor supply measure is hours worked per person 15-64 in the taxed market sector. The two principal margins of work effort are hours actually worked by employees and the fraction of the working age population that work. Paid vacations, sick leave, and holidays are hours of non working time. The time of someone working in the underground economy or in the home sector is not counted. Other things equal, a country with more weeks of vacations and more holidays will have a lower labor supply in the sense that I am using the term. I focus only on that part of working time that the resulting labor income is taxed.

\footnotetext{
${ }^{1}$ For Italy the gross domestic product (GDP) is reduced by 20 percent because Italy's GDP statistics include estimates of the output of the underground untaxed economy. My theory is concerned with the above-ground taxed economy, and I want GDP for this sector. This is why I do not follow Maddison (1995, pp. 241-50) and increase the OECD labor supply numbers by 16.0 percent in the 1970-74 period and 17.6 percent in the 199396 period.
} 
Table 1

GDP, Labor Supply, and Productivity

Major Advanced Countries: 1993-96

\begin{tabular}{lccc} 
Country & $\begin{array}{c}\text { GDP } \\
\text { 15-64; } \text { U.S. }=100\end{array}$ & $\begin{array}{c}\text { Hours per person } \\
15-64 ; \text { U.S. }=100\end{array}$ & $\begin{array}{c}\text { GDP per hour } \\
\text { U.S. }=100\end{array}$ \\
\hline Germany & 74 & 75 & 99 \\
France & 74 & 68 & 110 \\
Italy & 57 & 64 & 90 \\
Canada & 79 & 88 & 89 \\
United Kingdom & 67 & 88 & 76 \\
Japan & 78 & 104 & 74 \\
United States & 100 & 100 & 100 \\
a OECD purchasing power parity GDP numbers & &
\end{tabular}

Table 1 reports the G-7 countries' GDP, labor supply, and productivity statistics for the 1993-96 period relative to the United States. Also reported are GDP per person aged 15-64 and labor productivities also relative to the United States. The important observation is that labor supply is much higher in Japan and the United States than it is in Germany, France, and Italy. Canada and the United Kingdom are in the intermediate range. Another observation is that U.S. per capita output is about 40 percent higher than in the European countries with most of the differences in output accounted for by differences in hours worked per person and not by differences in productivity, that is, in output per hour. Indeed, the OECD statistics indicate that French productivity is 10 percent higher than it is in the United States. In Japan, 
the per capita output difference is accounted for by lower productivity and not by lower labor supply.

Table 2

Labor Supply, Productivity, and GDP

Major Advanced Countries: 1970-74

\begin{tabular}{lccc} 
Country & $\begin{array}{c}\text { GDP } \\
\text { 15-64; U.S. }=100\end{array}$ & $\begin{array}{c}\text { Hours per person } \\
\text { 15-64; U.S. }=100\end{array}$ & $\begin{array}{c}\text { GDP per hour } \\
\text { U.S. }=100\end{array}$ \\
\hline Germany & 75 & 105 & 72 \\
France & 77 & 105 & 74 \\
Italy & 53 & 82 & 65 \\
Canada & 86 & 94 & 91 \\
United Kingdom & 68 & 110 & 62 \\
Japan & 62 & 127 & 49 \\
United States & 100 & 100 & 100
\end{tabular}

Table 2 shows a very different picture in the 1970-74 period. The difference is not in per capita GDP. Then, European per capita GDP was about 70 percent of the U.S. level, as it was in 1993-96 and is today. However, the reason for the lower output in Europe was not fewer market hours, as was the case in the 1993-96 period, but rather lower output per hour. In 1970-74, Europeans worked more than Americans. The exception is Italy. Some change resulted in these changes in labor supply. 


\section{Theory Used}

The theory used is standard. It is the theory used in quantitative studies of business cycles (Cooley (1995)), of depressions (Cole and Ohanian (1999) and Kehoe and Prescott (2002)), of public finance issues (Christiano and Eichenbaum (1992) and Baxter and King (1993)), and of the stock market (McGrattan and Prescott $(2000,2003)$ and Boldrin, Christiano, and Fisher (2001)). In focusing on labor supply, I am following Lucas and Rapping (1969), Lucas (1972), Kydland and Prescott (1982), Hansen (1985), and Auerbach and Kotlikoff (1987).

This theory has a stand-in household that faces a labor-leisure decision and a consumption-savings decision. The preferences of this stand-in household are ordered by

$$
E\left\{\sum_{t=0}^{\infty} \beta^{t}\left(\log c_{t}+\alpha \log \left(100-h_{t}\right)\right)\right\}
$$

Variable $c$ denotes consumption, and $h$ denotes hours of labor supplied to the market sector per person per week. The discount factor $0<\beta<1$ specifies the degree of patience, with a higher value being more patient. The parameter $\alpha>0$ specifies the value of nonmarket productive time to the household. Given that on a per person basis a household has about 100 hours of productive time a week, nonmarket productive time is $100-h$ hours per week per working-age person in the household. Following the tradition in macroeconomics, this nonmarket productive time will be referred to as leisure even though much of it is time allocated to working in the nonmarket sector, and in the underground market sector. The important thing for this analysis is that any production using this time is not taxed.

In the model economy used, the household owns the capital and rents it to the firm. This is an assumption of convenience because the findings are identical if the firm owns the 
capital and the household owns the firm, or if the firm is partially debt financed. The law of motion governing the capital stock is

$$
k_{t+1}=(1-\delta) k_{t}+x_{t} .
$$

The theory also has a stand-in firm with a Cobb-Douglas production function,

$$
y_{t}=c_{t}+x_{t}+g_{t} \leq A_{i t} k_{t}^{\theta} h_{t}^{1-\theta} .
$$

Here $y$ denotes output, $c$ consumption, $x$ investment, $g$ pure public consumption, and $k$ the capital stock. The capital cost share parameter is $0<\theta<1$, and the total factor productivity parameter of country $i$ at date $t$ is $A_{i t}$. I will not specify the process on $\left\{A_{i t}\right\}$ because it plays no role in the inference being drawn, except to implicitly restrict the process governing its evolution in such a way that results in the existence of a competitive equilibrium.

The household's date $t$ budget constraint is

$$
\left(1+\tau_{c}\right) c_{t}+\left(1+\tau_{x}\right) x_{t}=\left(1-\tau_{h}\right) w_{t} h_{t}+\left(1-\tau_{k}\right)\left(r_{t}-\delta\right) k_{t}+\delta k_{t}+T_{t},
$$

where $w_{t}$ is the real wage rate, $r_{t}$ the rental price of capital, $\tau_{c}$ the consumption tax rate, $\tau_{x}$ the tax investment tax, $\tau_{h}$ the marginal labor tax rate, $\tau_{k}$ the capital income tax rate, and $T_{t}$ transfers. I emphasize that the marginal and average labor income taxes will be very different.

All taxes revenue except for that used to finance the pure public consumption are given back to the households either as transfer payments or in kind. These transfers are lump sum being independent of a household income. Most public expenditures are substitutes for private consumption in the G-7 countries. Here I will assume that they substitute on a oneto-one basis for private consumption with the exception of military expenditures. The goods and services in question are mostly publicly provided education, health care, protection 
services, and even judiciary services. My estimate of pure government consumption $g$ is two times military's share of employment times GDP.

In having only one consumption good, I am following Christiano and Eichenbaum (1992). Rogerson (2003) has found that this one consumption good abstraction is not a good one for studying aggregate labor supply in the Scandinavian countries. One possible reason for this is that some publicly provided goods, such as child care for working parents, must be treated as a separate good. Often the receipt of this good is contingent on working, and this must be taken into account in the household's constraint set. However, the one consumption good abstraction used in this study is a reasonable one for the set of countries considered in this study.

This is a far simpler tax system than the one employed in any of the G-7 countries. Introducing accelerated depreciation and investment tax credits would affect the price of the investment good relative to the consumption good, but would not alter the inference drawn in this lecture. Similarly, introducing a corporate sector, with dividends not taxed, as is generally the case in Europe, or taxed as they are in the United Sates as ordinary income, would not alter any conclusion significantly. For further details on these issues, see McGrattan and Prescott (2002). What is important is the price of consumption relative to leisure, and it is determined by the consumption tax rate $\tau_{c}$ and the labor income tax rate $\tau_{h}$.

The most important parameter that will enter the equilibrium relation that I use to predict the consequence of the tax system is the preference parameter $\alpha$, which measures the value of leisure relative to consumption. The capital cost share parameter $\theta$ also enters the relation, but is of less importance. 


\section{Key equilibrium relation}

The labor and consumption tax rates can be combined into a single tax rate $\tau$, which I call the effective marginal tax rate on labor income. It is the fraction of additional labor income that is taken in the form of taxes holding investment, or equivalently savings, fixed. From the household's budget constraint,

$$
\tau=\frac{\tau_{h}+\tau_{c}}{1+\tau_{c}} .
$$

Two first-order conditions are used to construct the key equilibrium relation that is used to predict labor supply. The first is that the marginal rate of substitution between leisure and consumption is equal to their price ratio; that is,

$$
\frac{\alpha /(1-h)}{1 / c}=(1-\tau) w .
$$

The second is the profit-maximizing condition that the wage equals the marginal product of labor; that is,

$$
w=(1-\theta) k^{\theta} h^{-\theta}=(1-\theta) y / h .
$$

From (6) and (7), the key relation is obtained, namely,

$$
h_{i t}=\frac{1-\theta}{1-\theta+\frac{c_{i t}}{y_{i t}} \frac{\alpha}{1-\tau_{i t}}} .
$$

The subscript $i$ denotes the country, and the subscript $t$ denotes the date.

This equilibrium relation clearly separates the intertemporal and intratemporal factors affecting labor supply. The intratemporal factor is captured by $1-\tau$, which distorts the relative prices of consumption and leisure at a point in time. The $c / y$ term captures intertemporal factors. If, for example, the effective tax rate on labor income is expected to be higher in the future, people will choose a lower current value for $c / y$, and current labor supply 
will be higher. The same is true if the current capital stock is low relative to its balanced growth path level. More formally, equilibrium $c / y$ is a function of the predictive probability distribution of future tax rates and productivities and the current capital stock. Knowing the value of this function and the current effective tax rate on labor income suffices for predicting current labor income.

In focusing on the role of taxes in determining aggregate labor supply, I am not implying that other factors are unimportant. Cole and Ohanian (1999) and Chari, Kehoe, and McGrattan (2003), using the discipline employed here, present strong evidence that other factors were important in accounting for the low labor supply in the United States in the 1930s. Similarly, Cole and Ohanian (2002) present evidence that the low labor supply in the United Kingdom in the interwar period was due to other factors, and Fisher and Hornstein (2002) find that labor market distortions that increased the real wage significantly above the competitive level were the major factor in accounting for the huge decline in German output in the 1928-32 period. In focusing on the role of marginal tax rates on labor income, I want to determine what role, if any, they play in accounting for the huge differences in labor supplies across this relatively homogenous set of market economies at a point in time and in accounting for large changes over time in labor supplies across these countries. ${ }^{2}$

The theory abstracts from many features of reality that affect labor supply, in particular, whether a married household has one or two wage earners. This issue is discussed briefly in the context of the change in the U.S. labor supply in conjunction with the change in the nature of the income tax schedule that occurred as a result of the 1986 U.S. Tax Reform Act.

\footnotetext{
${ }^{2}$ Three recent studies that address issues related to the ones considered in this lecture are Davis and Henrekson (2003), Olovsson (2003), and Nickell (2003).
} 


\section{Estimating Tax Rates}

The theory has the household paying the taxes. Consequently, it is necessary to adjust the national income accounts to be consistent with this theoretical framework. The adjustment, which is a major one, is to treat indirect taxes less subsidies as net taxes on final product. This means removing net indirect taxes as a cost component of GDP and reducing final product components.

In using national accounts (SNA) data to estimate tax rates and making the distinction between prices facing producers and consumers, I am following Mendoza, Razin, and Tesar (1994). There are some important differences in the approach with my estimated tax rates being in greater part model economy dependent. In what follows the capital letters are SNA statistics. I assumed that two-thirds of these indirect taxes net of subsidies fall directly on private consumption expenditures and that the remaining one-third is distributed evenly over private consumption and private investment. Thus, net indirect taxes on consumption, $I T_{c}$, are

$$
I T_{c}=\left[2 / 3+1 / 3 \frac{C}{C+I}\right] I T,
$$

where $C$ is SNA private consumption expenditures, $I$ is SNA private investment, and $I T$ is net indirect taxes.

The model economy's consumption $c$ and output $y$ are

$$
c=C+G-G_{m i l}-I T_{c} \text { and } \quad y=G D P-I T .
$$

The motivation for this assignment of indirect taxes is that most indirect taxes fall on consumption whether these taxes are a value-added tax, a sales tax, an excise tax, or a property tax. Some taxes, such as fuel taxes on diesel fuel used by trucks that transport 
goods, property taxes on office buildings, and sales taxes on equipment purchases by businesses, fall on all forms of product. My estimate of the consumption tax rate is

$$
\tau_{c}=\frac{I T_{c}}{C-I T_{c}} .
$$

There are two taxes on labor income, the income tax with marginal rate $\tau_{\text {inc }}$ and the social security tax with marginal rate $\tau_{s s}$. My estimate of the social security tax rate is simply

$$
\tau_{s s}=\frac{\text { Social Security Taxes }}{(1-\theta)(G D P-I T)} .
$$

The denominator is labor income if labor is paid its marginal product.

In some countries, some social security taxes are savings because retirement benefits increase with income. But, this is a marginal tax rate. If someone works an additional year, typically there are no additional benefits. In the United States the marginal savings factor is tiny. First, using a 4 percent discount rate and a 2 percent growth rate in the real wage, which are numbers for the U.S. economy in the twentieth century (McGrattan and Prescott (2003)), the present value of benefits is only one-quarter of the present value of contributions. Second, the social security payment benefit scheme is highly progressive. Third, benefits to married couples typically go up little if both work rather than if only one works. Fourth, beginning in the early 1990s, a significant part of social security benefits is subject to income taxes for many people. Fifth, for many older workers their current-year taxable labor income has little or no consequences for the retirement benefits they receive.

Social security taxes are listed as an expenditure of the household sector in the SNA. They include taxes used to finance health care and unemployment payments, and not just taxes used to finance retirement programs. These taxes are typically proportional taxes on labor income, and they are treated as such in this analysis. In the SNA these taxes are treated 
as part of compensation, as theory says they should be, when they are paid by the employer, which is typically the case.

The average, not marginal, income tax rate is

$$
\bar{\tau}_{\text {inc }}=\frac{\text { Direct Taxes }}{G D P-I T-\text { Depreciation }} .
$$

Direct taxes are those paid by households and do not include corporate income taxes. Like social security taxes, they are listed as an expenditure of the household sector in the SNA.

My estimate of the marginal labor income tax rate is

$$
\tau_{h}=\tau_{s s}+1.6 \bar{\tau}_{i n c} .
$$

The most problematic number in my analysis is the 1.6 factor that reflects the fact that the marginal income tax rates are higher than the average tax rates. The 1.6 number was selected because it results in the marginal income tax rate obtained using the Feenberg and Coutts (1993) methodology for the United States in both the 1970-74 and 1993-96 periods.

Feenberg and Coutts' methodology uses a representative sample of tax records to compute the marginal tax rate on labor income by determining how much tax revenue increases if every household's labor income is changed by 1 percent. The total change in tax receipts divided by the total change in labor income is the Feenberg-Coutts estimate of the marginal income tax rate on labor income. I will return to this point later.

\section{Predicted and Actual Labor Supplies}

There are two parameters that must be specified before formula (8) can be used to predict labor supply. The first parameter is the capital share parameter $\theta$ in the production function. In all the countries, in both periods this number is close to the average of 0.3224 , so $\theta$ is set equal to this value for all countries in both periods. The second parameter is the 
utility of leisure parameter $\alpha$. This parameter was chosen so that overall the average labor supply of the non-outlier observations, of which there are two, are close to actual. The value chosen is 1.54 .

Table 3 reports the actual and predicted labor supplies for the G-7 countries in the 199396 period. The predicted values are surprisingly close to the actual values with the average difference being only 1.14 hours per week. I say that this number is surprisingly small because this analysis abstracts from labor market policies and demographics which have consequences for aggregate labor supply and because there are significant errors in measuring the labor input.

Table 3

G-7 Countries' Predicted and Actual Labor Supply: 1993-96

\begin{tabular}{|l|c|c|c|c|}
\hline Country & Tax rate $\tau$ & $c / y$ & \multicolumn{2}{|c|}{ Hours per person 15-64 per week } \\
\hline & & & Actual & Predicted \\
\hline Germany & & & & \\
France & 0.59 & 0.74 & 19.3 & 19.5 \\
Italy & 0.59 & 0.74 & 17.5 & 19.5 \\
Canada & 0.64 & 0.69 & 16.5 & 18.8 \\
United Kingdom & 0.52 & 0.77 & 22.9 & 21.3 \\
Japan & 0.44 & 0.83 & 22.8 & 22.8 \\
United States & 0.37 & 0.68 & 27.0 & 29.0 \\
\hline
\end{tabular}

The important observation is that the low labor supplies in Germany, France, and Italy are due to high tax rates. In these countries if someone works more and produces 100 
additional euros of output, that individual gets to consume only 40 euros of additional consumption and pays directly or indirectly 60 euros in taxes.

Table 4 reports the predicted and actual values for the 1970-74 period. For Italy it is clear that some factor other than taxes depressed labor supply in the early 1970s. This period was one of political instability in Italy, and quite possibly cartelization policies reduced equilibrium labor supply as in the Cole and Ohanian (2002) model of the U.S. economy in the 1935-39 period. The overly high prediction for labor supply for Japan in the 1970-74 period may in significant part be the result of my utility function having too little curvature with respect to leisure and, as a result, the theory overpredicts when the effective tax rate on labor income is low. Another possible reason for the overprediction may be a measurement error. The 1970-74 Japanese labor supply statistics are based on establishment surveys only because at that time household surveys were not conducted. In Japan the household survey gives a much bigger estimate of hours worked in the period when both household- and establishment-based estimates are available. In the other countries household surveys are used to estimate labor supply. 
Table 4

G-7 Countries' Predicted and Actual Labor Supply: 1970-74

\begin{tabular}{|l|c|c|c|c|}
\hline Country & Tax rate $\tau$ & $c / y$ & \multicolumn{2}{|c|}{ Hours per person per week } \\
\hline & & & Actual & Predicted \\
\hline Germany & 0.52 & 0.66 & 24.6 & 24.6 \\
France & 0.49 & 0.66 & 24.4 & 25.4 \\
Italy & 0.41 & 0.66 & 19.2 & 28.3 \\
Canada & 0.44 & 0.72 & 22.2 & 25.6 \\
United & 0.45 & 0.77 & 25.9 & 24.0 \\
Kingdom & 0.25 & 0.60 & 29.8 & 35.8 \\
Japan & 0.40 & 0.74 & 23.5 & 26.4 \\
\hline United States & & & & \\
\hline
\end{tabular}

An important observation is that when European and U.S. tax rates were comparable, European and U.S. labor supplies were comparable. At the aggregate level, where idiosyncratic factors are averaged out, people are remarkably similar across countries. This is true not only for the G-7 countries, but as shown by Bergoeing et al. (2002) for Chile and Mexico and by Kydland and Zarazaga (2002) for Argentina as well. Apparently, idiosyncratic preference differences average out and result in the stand-in household having almost identical preferences across countries.

I find it surprising that virtually all the large differences in the U.S. labor supply and those of Germany and France are due to differences in tax systems. I expected institutional constraints on the operation of labor markets and the nature of the unemployment benefit 
system to be of major importance. They do appear to be important in Italy in the 1970-74 period.

\section{Changes in U.S. Labor Supply}

An interesting feature of the data is that U.S. labor supply increased by 10 percent between 1970-74 and 1993-96, yet the marginal tax rate on labor remained at 0.40 . The fact that all the increase in labor supply was by married women and not by males or by single females suggests that the appropriate marginal tax rate may have fallen with the flattening of the income tax rate schedule associated with the tax reforms of the 1980s, in particular, the 1986 tax reform (McGrattan and Rogerson (1998)). The U.S. Department of the Treasury $(1972,1994)$ lists the number of married households' tax returns by adjusted gross income categories as well as reports the income tax schedule. These data show that the marginal tax rate for large changes in income such as those that would occur from moving between a oneearner household to a two-earner household was significantly higher in 1972 than it was in 1994.

Households switching between having one and two wage earners probably faced lower marginal tax rates in the 1993-96 period than in the 1970-74 period, even though the Feenberg-Coutts marginal income tax rates are the same. This possibility is illustrated by the following example of a two-person household. In the early period, if the working individual in the household increases hours worked by a small amount, the marginal income tax on the additional labor income is 20 percent, which is the Feenberg-Coutts estimate for that period. However, if the household doubles its labor supply by switching from a one-earner to a twoearner household, the marginal income tax rate on the additional labor income is 40 percent for this illustrative numerical example. 
Illustrative Example

Before Tax Reform

\begin{tabular}{|c|c|c|c|c|}
\hline Earners & Earnings & Taxes & Average & "Marginal" \\
\hline $\mathbf{1}$ & $\mathbf{1 0}$ & $\mathbf{1 . 3}$ & $\mathbf{1 3 . 0 \%}$ & $\mathbf{2 0 \%}$ \\
\hline 2 & 20 & 5.3 & 26.5 & $40 \%$ \\
\hline
\end{tabular}

After Tax Reform

\begin{tabular}{|c|c|c|c|c|}
\hline Earners & Earnings & Taxes & Average & "Marginal" \\
\hline 1 & 10 & 1.5 & $10.0 \%$ & $20 \%$ \\
\hline $\mathbf{2}$ & $\mathbf{2 0}$ & $\mathbf{2 . 6}$ & $\mathbf{1 3 . 0 \%}$ & $\mathbf{2 0 \%}$ \\
\hline
\end{tabular}

The situation is very different in 1993-96, when the household has two earners.

Small changes in labor supply in this case are still subject to a 20 percent tax rate as in the 1970-74 period, which is what the Feenberg-Coutts method finds for that period. However, the marginal income tax on the labor income associated with switching between a one-earner and a two-earner household is only 20 percent, not 40 percent as it was in the 1970-74 period.

This issue of the effect of the nature of the income tax schedule on labor supply for households with two potential wage earners warrants more attention. Feldstein (1995) examines the consequences of the 1986 Tax Reform Act using a Treasury Department panel of more than 4,000 tax forms and finds micro evidence consistent with this hypothesis. It is further supported in the Feldstein and Feenberg (1993) analysis of the Clinton Tax Plan.

Some macro evidence is provided by what happened subsequent to the 1998 Spanish tax reform that flattened the Spanish income tax schedule in much the same way that the 1986 U.S. tax reform flattened the U.S. tax schedule. Subsequently, Spanish labor supply increased by 12 percent and tax revenue by a few percent. If the change in the factor that 
converts the average income tax rate to a marginal tax rate were the same in the United States and Spain and sufficiently large to increase U.S. labor supply by 10 percent, then the predicted increase in Spanish labor supply would be the observed 12 percent. More research is needed to determine whether the hypothesis that the flattening of the tax schedule is the principal reason for the large increases in labor supply in both the United States and Spain subsequent to their tax reforms.

The welfare gains from reducing the effective marginal tax rate on labor income in the high tax rate countries are large. If France were to reduce its effective tax rate on labor income from 60 percent to the U.S. 40 percent rate, the welfare of the French people would increase by 19 percent in terms of lifetime consumption equivalents. This is a large number for a welfare gain. This estimate of the welfare gain takes into consideration the reduction in leisure associated with the change in the tax system and the cost of accumulating capital associated with the higher balanced growth path. The reduction in leisure is from 81.2 hours a week to 75.8 hours, which is a 6.6 percent decline in leisure. I was surprised to find that this large tax rate decrease did not lower tax revenues. ${ }^{3}$

The welfare gains if the United States reduced its marginal tax rate on labor income are smaller. If the tax rate is reduced from 40 percent to 30 percent, the gains in terms of lifetime consumption equivalents are 7 percent.

\footnotetext{
${ }^{3}$ Mendoza and Tesar (2002) also find that revenue is maximized with a tax rate slightly above 50 percent.
} 


\section{Implications of Findings: U.S. Social Security Reform}

If labor supply is fixed, a pay-as-you-go social security system cannot be converted to a fully funded system in a way that makes every generation better off. If, however, the labor supply is not fixed, the transition can be made in a way that makes every generation better off. The only issue is how long the transition will take. Using the elasticity of labor supply number obtained in the first part of this lecture, I now will explore this issue of how long such a transition will take.

The model economy is modified is two respects. First, I follow Auerbach and Kotlikoff (1987) and use the overlapping generational structure rather than the infinitely lived family structure employed in Section $1 .^{4}$ In the modified structure, the key relation used to forecast labor supply continues to hold. Second, the technology assumed has perfect substitution between capital and labor. The productivity of labor grows at the rate of 2 percent a year, which implies that the real wage will grow at 2 percent a year as it has on average throughout the twentieth century. The productivity of capital is constant and is such that the after-tax return is 4 percent.

Alternatively, I could have assumed that capital income tax rates, which are not formally modeled, are adjusted so as to maintain a 4 percent return on capital if the capital/output ratio changes as a result of the reform. This 4 percent return is the after-tax real return that has prevailed in the United States in the 1880-2002 period (McGrattan and Prescott (2003)). Having some dynastic families would also work in the direction of keeping the interest rate constant.

\footnotetext{
${ }^{4}$ See the July 1999 issue of the Review of Economic Dynamics, which is devoted entirely to studies of the U.S. social security system. These studies are much richer in detail than this one. But they do not use the utility function used in this study, and as a result my results are different. Conesa and Garriga (2003) address the status quo problem in social security reform.
} 
I assume that an equal number of people begin their working career every year at 22 , they work for 41 years, and then they live 19 additional years. The implies they retire at 63 which is the average retirement age. They receive social security benefits equal to 0.319 of the wage that prevailed when they are 66 beginning when they are 67 and continuing for 14 additional years. In fact, for the U.S. system, the wage base is the one that prevailed when an individual is 60 years old, so the replacement rate is approximately 36 percent. The effective tax rate on labor income is 40 percent, as it is in the United States, with 10 percent of this being social security retirement tax. The reason that 10 percent is used rather than the U.S. 12.4 percent social security tax rate is that some U.S. social security taxes are used to provide disability and survivors' insurance in the United States.

The assumption of no population growth is not realistic and introduces two errors. These errors, however, are of opposite sign and offsetting, so this illustrative example is still valid for building good quantitative economic intuition. The first error is that the relative number of people with social security claims is smaller if population growth is positive. This reduces the initial implicit liabilities relative to GDP of the pay-as-you-go system. The second error is that with a growing population the pay-as-you-go system will have higher levels of benefit payments associated with a given social security retirement tax. This increases the implicit liabilities of the current system. The pay-as-you-go system that I consider has the property that social security benefits paid are equal to social security taxes collected.

The model economy's time period is a year. The steady state of a pay-as-you-go system and a fully funded system are reported in Table 5. With the fully funded system, steady-state labor supply is 11 percent higher, consumption 17 percent higher, and welfare in 
lifetime consumption equivalents 9 percent higher. The problem with just switching from the current pay-as-you-go system to a fully funded system is that the initial old would suffer. The following reform makes all better off. There are still better reforms than this one, in particular, plans that have tax rates that depend upon age at the time of reform.

\section{Table 5}

Steady States for Two Social Security Systems

\begin{tabular}{lcc} 
Variable & Pay-As-You-Go System & Fully Funded System \\
\hline Net Output & 100 & 123 \\
Capital/Net Output Ratio & 2.77 & 4.91 \\
Labor Supply & 100 & 111 \\
$\begin{array}{l}\text { Consumption per Person } \\
\text { Social Security Liabilities }\end{array}$ & 100 & 117 \\
Relative to Net Output & 4.62 & 0.00 \\
$\begin{array}{l}\text { Welfare in Lifetime } \\
\text { Consumption Equivalents }\end{array}$ & 100 & 109 \\
Effective Labor Tax Rate & $40.00 \%$ & $27.05 \%$
\end{tabular}

\section{Proposed Reform}

People are given the option to continue with the current system or to shift to a new system. With the new system, 8.7 percent of wage income is put into an individual account 
with the government that earns a 4 percent real return. Upon retirement, savings in this account are annuitized. Effectively, people have the option to have their tax rate on labor reduced from 40 percent to 31.3 percent and to save 8.7 percent of their labor income in a government retirement account or to continue with the current social security system. With the reform, non-social security transfers are left unchanged.

Table 6

Government Social Security Liabilities Relative to GNI and the Capital/Output Ratio Subsequent to Reform

\begin{tabular}{ccc} 
Period & $\frac{\text { Soc.Sec.Liabilities }}{\text { GNI }}$ & $\frac{\text { Capital }}{\text { Output }}$ \\
\hline 1 & 2.30 & 2.71 \\
15 & 1.57 & 2.80 \\
30 & 0.63 & 3.08 \\
45 & 0.00 & 3.31 \\
60 & 0.00 & 3.32
\end{tabular}

Steady-state social security liabilities with the pay-as-you-go system are large: 4.62 times gross national income (GNI). With the reform, those aged 37 and younger choose the new system. The welfare gain to the 22-year-old at the time of the change exceeds 4 percent in lifetime consumption equivalents. Associated with the change, the capital/annual-output ratio increases from 2.7 to 3.3 , as seen in Table 6. This increase takes 45 years. 
Table 6 shows that pension liabilities of the pay-as-you-go system are large, being 2.30 times GDP. With the new system, the decline steadily and becomes zero 35 years after the reform.

\section{Some equity considerations}

In the model world all individuals earn the same wage when, in fact, some people earn higher wages than others. Given that earning a 4 percent after-tax real return is an attractive investment, equity considerations suggest an upper bound on contributions. Similarly, lower income households should have the right to contribute more than 8.7 percent of their labor income.

Still another consideration is how to deal with married couples. An equitable solution is that each party has an account and household contributions are split equally between the two accounts with the contribution limit discussed above applying to an individual account and not to a household account. There will be some who are so unfortunate that the amount in their account will be insufficient to provide for a minimal acceptable retirement. This suggests adding means-tested supplementary benefits.

Some may ask, why force people to save, as this scheme does. The answer is that it gets around the time inconsistency problem. Some individuals will not save if they know that others will provide for their consumption whether the others are taxpayers, family members, or charities.

\section{Concluding Remarks}

In this study, in the process of determining the effect of differences in effective marginal labor tax rates on labor supply across countries and time in the advanced industrial countries, I have estimated the elasticity of labor supply and have found it to be large, nearly 
3 when the fraction of time allocated to market is in the neighborhood of the current U.S. level. This estimate of the elasticity is essentially the same one that is needed to account for business cycle fluctuations. That this elasticity is large is good news. If labor supply were inelastic, the advanced industrial countries would face a cruel choice of either increasing taxes on the young, thereby lowering young people's welfare, or not honoring the promises made to the old, making the old worse off.

The high labor supply elasticity does mean that as populations age, promises of payments to the current and future old cannot be financed by increasing tax rates. These promises can be honored by reducing the effective marginal tax rate on labor income and moving toward retirement systems with the property that benefits on margin increase proportionally to contributions. Requiring people to save for their retirement years is not a tax and does not reduce labor supply. As the illustrative example establishes, such a system benefits the currently young workers and future workers while honoring promises made to the old.

One factor that I ignored in my social security reform example was that a larger capital/labor ratio increases the wages with any reasonably aggregate production function. If this factor is taken into consideration, the welfare gains are bigger. It is beyond the scope of this lecture to more than scratch the surface of how best to reform the social security retirement system and what the resulting welfare gains would be. But it is clear, given the high responsiveness of labor supply to marginal labor tax rates, that the potential gains are great. 


\section{References}

Auerbach, Alan J. and Kotlikoff, Laurence J. Dynamic Fiscal Policy. Cambridge:

Cambridge University Press, 1987.

Baxter, Marianne and King, Robert G. "Fiscal Policy in General Equilibrium." American Economic Review, June 1993, 83(3), pp. 315-34.

Bergoeing, Raphael; Kehoe, Patrick J.; Kehoe, Timothy J.; and Soto, Raimundo. “A Decade Lost and Found: Mexico and Chile in the 1980s." Review of Economic Dynamics, January 2002, 5(1), pp. 166-205.

Boldrin, Michele; Christiano, Lawrence J.; and Fisher, Jonas D.M. "Habit Persistence, Asset Returns, and the Business Cycle.” American Economic Review, March 2001, 91(1), pp. 149-66.

Chari, V.V.; Kehoe, Patrick J.; and McGrattan, Ellen R. "Accounting for the Great Depression." Federal Reserve Bank of Minneapolis Quarterly Review, Spring 2003, 27(2), pp. 2-8.

Christiano, Lawrence J. and Eichenbaum, Martin. "Current Real-Business-Cycle Theories and Aggregate Labor-Market Fluctuations." American Economic Review, June 1992, 82(3), pp. 430-50.

Cole, Harold L. and Ohanian, Lee E. "The Great Depression in the United States from a Neoclassical Perspective." Federal Reserve Bank of Minneapolis Quarterly Review, Winter 1999, 23(1), pp. 2-24.

. "The Great U.K. Depression: A Puzzle and Possible Resolution." Review of Economic Dynamics, January 2002, 5(1), pp. 19-44.

Conesa, Juan Carlos and Garriga, Carlos. "The Status Quo Problem in Social Security Reforms.” Manuscript, December 2001. Macroeconomic Dynamics, forthcoming, November 2003.

Cooley, Thomas F., ed. Frontiers of Business Cycle Research. Princeton: Princeton University Press, 1995. 
Davis, Stephen J. and Henrekson, Magnus. "Tax Effects on Work Activity, Industry Mix and Shadow Economy Size: Evidence From Rich-Country Comparisons." Mimeo, University of Chicago Graduate School of Business, 2003.

Feenberg, Daniel R. and Coutts, Elisabeth. "An Introduction to the TAXSIM Model." Journal of Policy Analysis and Management, Winter 1993, 12(1), pp. 189-94.

Feldstein, Martin. "The Effect of Marginal Tax Rates on Taxable Income: A Panel Study of the 1986 Tax Reform Act." Journal of Political Economy, June 1995, 103(3), pp. $551-72$.

Feldstein, Martin and Feenberg, Daniel R. "Higher Tax Rates with Little Revenue Gain: An Empirical Analysis of the Clinton Tax Plan.” Tax Notes, March 22, 1993, 58, pp. $1653-57$.

Fisher, Jonas D.M. and Hornstein, Andreas. "The Role of Real Wages, Productivity, and Fiscal Policy in Germany's Great Depression 1928-1937." Review of Economic Dynamics, January 2002, 5(1), pp. 100-27.

Hansen, Gary D. "Indivisible Labor and the Business Cycle." Journal of Monetary Economics, November 1985, 16(3), pp. 309-27.

Kehoe, Timothy J. and Prescott, Edward C. "Great Depressions of the $20^{\text {th }}$ Century." Review of Economic Dynamics, January 2002, 5(1), pp. 1-18.

Kydland, Finn E. and Prescott, Edward C. "Time to Build and Aggregate Fluctuations." Econometrica, November 1982, 50(6), pp. 1345-70.

Kydland, Finn E. and Zarazaga, Carlos E.J.M. “Argentina's Lost Decade.” Review of Economic Dynamics, January 2002, 5(1), pp. 152-65.

Lucas, Robert E. Jr. "Expectations and the Neutrality of Money." Journal of Economic Theory, April 1972, 4(2), pp. 103-24.

Lucas, Robert E. Jr. and Rapping, Leonard A. "Real Wages, Employment, and Inflation." Journal of Political Economy, September/October 1969, 77(5), pp. 721-54. 
Maddison, Angus. Monitoring the World Economy: 1820-1992. Development Centre Studies. Paris: Organisation for Economic Co-operation and Development, 1995.

McGrattan, Ellen R. and Prescott, Edward C. "Is the Stock Market Overvalued?" Federal Reserve Bank of Minneapolis Quarterly Review, Fall 2000, 24(4), pp. 20-40.

. "Taxes, Regulations, and the Value of U.S. Corporations: A General Equilibrium Analysis." Federal Reserve Bank of Minneapolis Staff Report 309, August 2002. . “Average Debt and Equity Returns: Puzzling?” American Economic Review, May 2003, 93(2), pp. 392-97.

McGrattan, Ellen R. and Rogerson, Richard. "Changes in the Hours Worked since 1950." Federal Reserve Bank of Minneapolis Quarterly Review, Winter 1998, 22(1), pp. $2-$ 19.

Mendoza, Enrique G.; Razin, Assaf; and Tesar, Linda L. "Effective Tax Rates in Macroeconomics: Cross-Country Estimates of Tax Rates on Factor Incomes and Consumption." Journal of Monetary Economics, December 1994, 34(3), pp. $297-$ 323.

Mendoza, Enrique G. and Tesar, Linda L. "Tax Competition v. Tax Coordination under Perfect Capital Mobility: The Supply-Side Economics of International Tax Competition." CEPR $4^{\text {th }}$ Conference of the Analysis of International Capital Markets Research Training Network, November 2002.

Nickell, Stephen. “Employment and Taxes.” Mimeo, Venice International Institute, 2003.

OCED. National Accounts of OECD Countries, Volume I : Main aggregates, CD-ROM on Beyond 20/20. Paris: OECD, January 2001.

Olovsson, Conny. “Why Do Europeons Work So Little?" Mimeo, International Institute for Economic Studies, Stockholm University, 2003.

Rogerson, Richard D. "The Employment Effects of Taxes.” Working paper presented at Dynamic Economics Conference in Honor of Edward C. Prescott, 29 April 2003, Federal Reserve Bank of Chicago. 
United Nations. 1979/80 Statistical Yearbook, $31^{\text {st }}$ issue. Department of International Economic and Social Affairs. New York: United Nations, 1981. . Yearbook of National Accounts Statistics: Main Aggregated 1980, Part 1 and Part 2. New York: United Nations, 1982. . Yearbook of National Accounts Statistics: Main Aggregated and Detailed Tables, Part 1 and Part 2. New York: United Nations, 2000.

U.S. Department of the Treasury, Internal Revenue Service. Statistics of Income, Individual Income Tax Returns 1972 and Individual Income Tax Returns 1994. Washington, DC: U.S. Government Printing Office. 


\section{Data Appendix}

1. Source of National Account statistics: United Nations $(1982,2000)$

2. Source of civilian employment, noncivilian employment, annual hours per employee, population aged 15-64: OECD Labor Database, Labor Market Statistics -

http:www1.oecd.scripts/cde/viewsubj.asp?SUBJNAME=labor\&SUBJNAME_E=Labour

Note: "Hours of work: manufacturing" data were used for Japan in 1970-71 because annual hours per employee for Japan in 1970-71 were not in the OECD Labor Database. These data were obtained from United Nations (1981). These are based on establishment study.

3. Source of PPP GDP numbers: OECD Annual National Account Database, Table B.3. OECD (2001):

http://www.sourceoecd.org/content/html/portal/statistics/statistics.htm?comm=statisti00 00\&tken=0043AA267D350C113500C0F5779995\#oecdstats

4. Source of income taxes and contributions for social security, United States: BEA table 3.2. - http://www.bea.gov/bea/dn/nipaweb/SelectTable.asp?Selected=Y\#S3

5. Source of National Account statistics for Spain: Instituto Nacional de Estadística (Spain Statistical Office) - http://www.ine.es/inebase/menu3i.htm\#15 Download of the annual national accounts for the period 1993-2001. 